İş ve İnsan Dergisi | The Journal of Human and Work

Y1l | Year: Ekim | October 2020

Cilt-Say1 | Volume-Issue: 7 (2)

ss I pp: $267-282$

doi: $10.18394 /$ iid. 644694

e-ISSN 2148-967X

http://dergipark.gov.tr/iid/

Research Article

\title{
İşyeri Nezaketsizliğinin Yaratıcı Çalışan Performansı Üzerindeki Etkisi: Lider-Üye Etkileşiminin Aracılık Rolü
}

\author{
The Effect of Workplace Incivility on Employee Creative Performance: The Mediator \\ Role of Leader-Member Exchange
}

Berat Çiçek $^{\mathrm{a}}$, Ahmet Çiçek ${ }^{\mathrm{b}}$

MAKALE BİLGISİ

Anahtar Kelimeler:

Issyeri Nezaketsizliği,

Yaratıcı Çalışan

Performansi, Lider Üye

Etkileşimi

Tarihler :

Geliş 9 Kasım 2019

Düzeltme geliș 6 Şubat 2020

Kabul 27 Nisan 2020

\begin{abstract}
ÖZ
İsyerlerindeki nezaketsiz davranışlar çalışanlar arasındaki ilişkileri sekteye uğratabilmekte, çalıșanların ve ișletmelerin ortaya koyacağl çıktılar üzerinde olumsuz etkilere neden olabilmektedir. Bu çalışmada işyeri nezaketsizliğinin yaratıcı çalışan performansı üzerindeki etkisi ve bu ikisi arasındaki ilișkide lider-üye etkileșiminin aracı; yaș ve çalıșma süresinin ise düzenleyici etkisinin ortaya konulması amaçlanmıştır. Bu bağlamda oluşturulan aracıl düzenleyici yapısal eșitlik modelini test etmek amacıyla veri toplamak için Malatya ilindeki özel sektör ve kamu kesimi çalışan ve yöneticileri ile bir anket çalışması gerçekleştirilmiştir. Yapılan araștırmanın sonucuna göre ișeri nezaketsizliği yaratıcı çalıșan performansını ve lider-üye etkileşimini olumsuz olarak etkilemektedir. Ayrıca işyeri nezaketsizliği ile yaratıcı çalışan performansı arasındaki ilișkide lider-üye etkileşimi aracı, mevcut ișyerinde çalıșma süresi ise düzenleyici role sahiptir.
\end{abstract}

\begin{abstract}
A B S T R A C T
Discourteous behaviours in workplaces may hamper the relations between employees and this may have negative effects on the outputs of employees and enterprises. In this study, the impact of workplace incivility on employee creative performance and the mediating effect of leadermember exchange and the moderator role of age and tenure on the relationship between these two were aimed to be examined. In this context, a questionnaire was conducted with private and public sector employees and managers in Malatya Province to collect data in order to test the moderated-mediation structural equality model formed. The results of the research indicate that workplace incivility adversely affects employee creative performance and leader-member exchange. In addition, leader-member exchange has a mediator role and tenure has a moderator role in the relationship between workplace incivility and employee creative performance.
\end{abstract}

a Corresponding author, Dr. Öğr. Üyesi, Muş Alparslan Üniversitesi, İktisadi ve İdari Bilimler Fakültesi, İşletme Bölümü, Muş, Türkiye.E-mail: b.cicek@alparslan.edu.trORCID:0000-0002-4584-5862

b Öğretim Görevlisi, Muş Alparslan Üniversitesi, Sosyal Bilimler MYO Muş, Türkiye, E-mail: a.cicek@alparslan.edu.tr. ORCID: 00000002-3787-2123 


\section{GíRiş}

Kişilerarası temel davranış kurallarına uymak ve sosyal zekaya göre hareket etmek, hayatın her alanında olduğu gibi iş yaşantısında da oldukça önemlidir (Pearson, Andersson, \& Porath, 2000). İşyerinde geçen süre düşünüldüğünde, insan hayatının büyük bir bölümünü kapsadığı gözümüze çarpmaktadır. Bireylerin hayatında böylesine büyük bir yere sahip olan iş yaşantısında, hayatın her alanında olduğu gibi etkin bir iletişim kurma çabası içerisinde olmamı gerekmektedir. Fakat birçoğumuzun şahit olduğu gibi kaba söz ve davranışlarla insanlar zaman zaman nezaketten uzaklaşmaktadır. Estes ve Wang'e (2008) göre bu durum hayatın diğer alanlarında farklı sonuçlar sergilese de iş yaşantısında bireylerin performanslarına etki etmektedir.

Yeni ve faydalı fikirlerin üretilmesi olarak tanımlanan yaratıcılık (Amabile, 1983), örgütsel etkinlik ve işletmelerin hayatta kalması için kilit bir faktör olarak kabul görmektedir (Shalley \& Gilson, 2004; Unsworth, 2001; Zhou \& Shalley, 2003). Bu nedenle günümüzdeki işletmelerin ayakta kalabilmesi, büyümesi ve rekabet edebilmesi için yaratıcı bir performans sergilemesi gerekmektedir. Bir makineden veya teçhizattan yaratıcılık beklemek mümkün değildir. $\mathrm{Bu}$ performansı gösterecek olan ise şüphesiz insan kaynaklarıdır. Bundan dolayı günümüz işletmeleri çalışanları en önemli kaynak olarak görmektedir. Çünkü işletmelere rekabet avantajını sağlayacak olan faktörlerden birisi de yaratıcı çalışan fikirleridir.

Araştırmacılara göre (Blau, 2017; Gouldner, 1960) sosyal bir varlık olan insan doğası gereği sosyal yaşantı içerisinde bir beklenti içerisindedir. $\mathrm{Bu}$ beklentiyi sosyal değişim teorisiyle açıklamakta ve sosyal değişimi; "Bir kişi bir başkasına iyilik yaptığında, her ne kadar kesin bir tarihi veya şeklini bilmese de bir karşılık beklentisi içerisinde olması" şeklinde tanımlamışlardır. Buradan hareketle bireylerin iletişim biçimlerinin, davranışlarının, tutumlarının bu teoriye dayanarak şekillendiği sık sık tartışılmaya başlanmıştır. İşyerindeki bu değişim beklentisi iki şekilde görülmektedir. İlki aynı seviye iki çalışan arasında olan beklenti, diğeri ise çalışan ve yönetici arasındaki ilişkide olan beklentidir.

Sosyal beklenti teorisinden türetilen ve işletmeler açısından önemli olan konuların başında lider-üye etkileşimi gelmektedir. Çalışanlar ile yöneticilerin arasındaki etkileşime odaklanan bu teori örgüt içi iletişim açısından da oldukça önemli bir yaklaşımdır. Liderler organizasyonun işleyişine her yönüyle tesir edebilmektedir. Çalışanların yaratıcılığını doğrudan etkileyebilecekleri gibi örgüt içerisindeki iletişimin seyrini de değiştirme gücüne sahiptir. Buradan hareketle çalışmada incelenen bir diğer değişken lider-üye etkileşimi olmuştur.

Çalışanların işletmeler açısından en önemli değer olduğu geniş kitlelerce kabul görmüş bir paradigmadır. Bu nedenle çalışanların davranışları birçok çalışmanın konusunu oluşturmaktadır. Bu çalışmada çalışanların yaratıcı performansını etkileyen bir unsur olarak işyeri nezaketsizliği ele alınmıştır. Bu bağlamda işyerindeki nezaketsizliğin yaratıcı performansa olan etkisi incelenmiş ve bu iki değişken arasındaki ilişkide lider-üye etkileşiminin, bireyin yaşının ve çalışma süresinin nasıl bir rol üstlendiği ortaya konulmaya çalışılmıştır. $\mathrm{Bu}$ amaçla kamu ve hizmet sektörü çalışanları üzerinde nicel bir araştırma gerçekleştirilmiştir. Araştırma sonucunda, işyeri nezaketsizliğinin yaratıcı performansı olumsuz etkilemesi ve bu ikisi arasındaki ilişkiye lider-üye etkileşiminin aracılık etmesi beklenilmektedir.

\section{KAVRAMSAL ÇERÇEVE}

\section{1. İşyeri Nezaketsizliği}

Nezaketsizlik Oxford (2019) online sözlükte "kaba veya mantıksız konuşma veya davranış olarak ifade edilirken", Türk Dil Kurumu (2019) online sözlüğünde "ince ve nazik olmama durumu, kabalık" olarak tanımlanmaktadır. Literatürde ise nezaketsizlik; geleneksel olarak kabul edilen norm ve değerlerin erozyonuna işaret eden topluluk standartlarının düşük seviyeli ihlalleri, olarak tanımlanmaktadır (LaGrange, Ferraro, \& Supancic, 1992). Leiter'a (2013) göre günümüzde insanlar birbirleriyle iyi geçinmekte zorlanıyor. Bunun sonucu olarak anaokullarından hastanelere kadar olan her türlü işyerinde bireyler arasındaki iletişim zorbalık, dokunulmazlık ve saldırganlık şikayetleri ile sekteye uğrayabiliyor.

İşyerindeki nezaketsizlik aynı zamanda bir zorbalık türü olarak karşımıza çıkıyor ve özellikle bir güç dengesizliği içeriyor. $\mathrm{Bu}$ durum düşmanca bir çalışma ortamı yaratırken, diğer yandan bir veya daha fazla kişiye yönelik tekrarlanabilen israrcı ve olumsuz bir eylemler bütününü temsil etmektedir (Lutgen-Sandvik, Tracy \& Alberts, 2007). Hiç şüphesiz bu tür davranışlar çalışanların moralini baltaladığı gibi işe başlama ve işgören devir hızını artırmakta, etkin ekip çalışmasını sabote etmekte, meslektaşlarına ve çalışanlara sıkıntı vermesine neden olmaktadır. $\mathrm{Bu}$ yönüyle işyeri nezaketsizliğini bir davranış bozukluğu olarak görmek mümkündür. 
Bazı bireyler sürekli olumsuz, küçümseyici davranışlar sergileyerek yöneticiler veya akranları ile iş birliği içinde çalışmayı reddetmekte, iş arkadaşının itibarına zarar veren dedikodular yaparak bunu yaymakta, arkadaşlarına lakap takma ve herhangi bir örgütsel düzeyde gelen girdiyi gizlemeyle çalışmaktadır. İşyerindeki bu tür nezaketsiz davranışlar düşmanca bir çalışma ortamının oluşumuna neden olabilmektedir (Felblinger, 2008). Ayrıca bu davranışlar işyerindeki nezaketsizliğin günlük işleyiş içerisinde görülebileceği en hafif halidir. Çünkü Pfifferling'e (2003) göre işyerindeki nezaketsizliğin bir üst boyutu zorbalıktır. Zorbalık ise küfürlü bir dil kullanımı, iş arkadaşını utandırma, ekip üyelerini başkalarının önünde eleștirme, bir takım üyesinden intikam peşine düşme ve hatta şiddet veya işten kovdurmakla tehdit etmeye kadar varabilmektedir. İşyeri nezaketsizliği birçok kuruma ve içinde çalışan insanlara sessizce zarar veren yaygın bir davranıştır. $\mathrm{Bu}$ nedenle çalışanların uzun bir hizmet döneminden sonra bile organizasyonlarını terk etmeyi düşünmelerine, organizasyonların bundan dolayı maddi bir külfetin altına girmelerine neden olabilmektedir. Dolayısıyla, organizasyonların iş yeri nezaketsizliğini görmezden gelmek yerine, üyelerinin iş yaşam kalitesini arttıran eylemler ve uygulamaları hayata geçirerek onları aktif olarak yönetmeleri gerekmektedir (Sguera, Bagozzi, Huy, Boss \& Boss, 2016). Çünkü bir işyerindeki kaba ve nezaket dışı davranışlar, organizasyonun iş ve işleyiși üzerinde negatif yönlü bir etki oluşturmaktadır. Anderson ve Pearson (1999) işyerindeki nezaketsizliğin nerelere varabileceğine dair bir model geliştirip adını nezaketsizlik sarmalı koymuştur. Nezaketsizlik sarmalı Şekil 1'de verilmiştir.

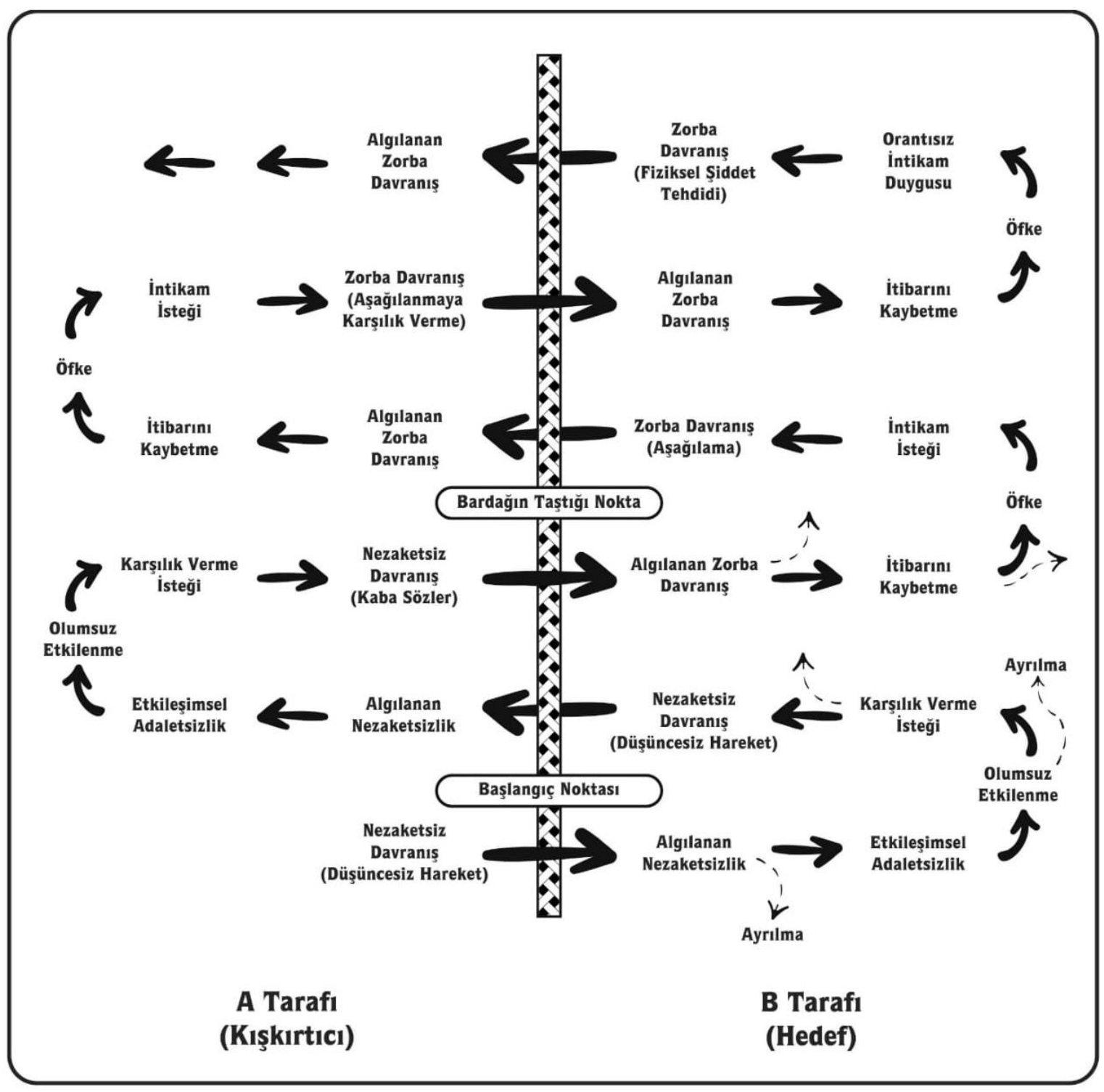

Şekil 1: Nezaketsizlik Sarmalı (Anderson \& Pearson (1999: 460) 
Hutton (2006) sarmalı şu şekilde açıklamaktadır: İlk olarak nezaketsiz bir davranışla başlayan süreç karş1 tarafın algısıyla şekillenmektedir. Kaba bir davranışın veya sözün hedef üzerindeki algısı nezaketsizlik ise bu duruma örnek olarak verilebilir. $\mathrm{Bu}$ durumda karşı taraf spiralden ayrılabilir veya spiralde kalırsa karşılaşabileceği potansiyel durumlar; olumsuz etkilenme, karşılık verme isteği ve nihayetinde nezaketsiz bir davranış olacaktır. $\mathrm{Bu}$ durumda nezaketsiz davranış genelde düşüncesiz bir hareket olabilmektedir. Tabi işin doğasına göre sarmalı değerlendirmek gerekmektedir. Örneğin bir inşaat alanında bağırmak oldukça normal bir davranışken, kütüphanede bağırmak oldukça nezaketsiz ve düşüncesiz bir davranış olarak karşılanacaktır. $\mathrm{Bu}$ nedenle algılanan nezaketsiz davranış formları organizasyondan organizasyona farklılık gösterebilmektedir. Nezaketsizliğin başlatan tarafa dönmesi olayları daha da derinleştirip "bardağın taşmasına" neden olacaktır. Burada artık işyeri nezaketsizliği intikam düşüncesiyle harmanlanıp işyeri zorbalığına kadar gidebilmektedir. $\mathrm{Bu}$ da her iki taraf açısından artık sonu gelmez karşılıklı bir çekişmeye dönüşebilmektedir. İtibar kaybı, sürekli hissedilen bir öfke ile harmanlanıp intikam duygusunu sürekli olarak karşılıklı tetikleyen bir hale bürünecektir.

\section{2. İşyeri Nezaketsizliği ve Yaratıcı Çalışan Performansı İlişkisi}

Yeni ve faydalı fikirlerin üretilmesi olarak tanımlanan yaratıcılık, örgütsel açıdan bireylerin yaratıcı fikirlerini ve bu fikirlerin ortaya çıkmasını sağlayacak olan destekleyici örgüt iklimlerini ifade etmektedir (Amabile, 1983). Başka bir deyişle yaratıc1 performans yaratıcılık potansiyelinin davranışsal bir tezahürüdür (Cummings \& Oldham, 1997). Birey açısından yaratıcılığı geliştirmek onu motive etmekten geçerken, örgütteki yaratıcı iklim açısından; iş arkadaşlarına yardım etmek, organizasyonu korumak, yapıcı önerilerde bulunmak, kendini geliştirmek ve iyi niyeti yaymak oldukça önemlidir (George \& Brief, 1992). Nobel fizik ödülü sahibi olan Arthur Schawlow da yaratıcılık konusunda içsel motivasyonun önemini vurgulamıştır. $\mathrm{Bu}$ motivasyon ilginç, dahil edici, heyecan verici, tatmin edici veya kişisel olarak zorlayıcı olduğunda insanları bir şeyler üzerinde çalışmaya sevk etmektedir. Ayrıca bireylerin kendiliğinden motive olduklarında en yaratıcı olacağına dair çok sayıda kanıt vardır (Amabile, 1997).

İşletmeler örgütsel inovasyonu başlatmak için yaratıcı çalışanlara ihtiyaç duyar. Beklendiği gibi, çalışanların yaratıcılığı, rekabet avantajı yaratmanın anahtarı olarak kabul edilmektedir (Coelho, Augustob, \& Lages, 2011). Çalışanlar, yaratıcılıkla alakalı kişisel özelliklere sahip olduklarında, karmaşık, zorlu işlerde çalıştıklarında ve işleri denetlendiğinde en yaratıcı işi ürettikleri gözlemlenmiştir. Fakat denetimin ve yaratıcı özelliklerinden herhangi birinin olmaması durumunda yaratıcı performansları olumsuz yönde etkilenmektedir (Oldham \& Cummings, 1996). İşletmeler, yaratıcı bireyler seçerek veya çalışanları geliştirerek çalışan yaratıcılığının faydalarından yararlanabilirler. Fakat çalışanları yalnızca kendi öğrenme yönelimlerine göre seçmenin yaratıcılı̆̆ 1 garanti etmeyeceğini, bunu sağlamak için çalışanlarının yaratıcı öz-yeterliliklerini sağlamanın gerekliliği unutulmamalıdır (Gong, Huang, \& Farh, 2009).

$\mathrm{Bu}$ tanımlamalardan hareketle, organizasyonlarda yaratıcılığı ortaya çıkarabilmek için iki önemli unsurdan bahsedilebilir. İlki organizasyonda yaratıcılığı tetikleyecek bir iklimin oluşturulması. İkincisi ise çalışanların yaratıcılığını ortaya çıkarabilmek için onları motive etmek veya içsel motivasyonu yüksek bireyleri işe almaktır.

Şiddet, saldırganlık, zorbalık, taciz, sapkınlık ve adaletsizlik her işyerinde kişilerarası kötü muamele ile ilgili bir formu temsil etmektedir (Cortina \& Magley, 2001). Araştırmalar, işletmelerde nezaketsiz davranışlar, örgütsel kısıtlamalar ve kişilerarası çatışmanın iş tatmini ve yaratıcılık ile olumsuz; zarar verici iş davranışı ile olumlu yönde seyrettiğini göstermektedir (Penney \& Spector, 2005). Çünkü baskı durumunda çalışanın öz yeterliliği azalır ve bu nedenle çalışanların yaratıcılığı zarar görür (Gutnick, Walter, Nijstad \& Dreu, 2012). Bu araştırmalardan yola çıkarak, çalışmada test edilmek üzere aşağıdaki hipotez üretilmiştir.

H1: İsyeri nezaketsizliği, yaratıcı iş performansı üzerinde negatif bir etkiye sahiptir

\subsection{Aracı Değişken Olarak Lider-Üye Etkileşimi}

Lider üye etkileşimi teorisi liderliğin yalnızca, liderin üyelerini etkileme süreci olarak değil de üyelerin de lideri etkilediği çift yönlü bir süreç olduğu varsayımıyla ortaya çıkmıştır (Graen \& UhlBien, 1995). Bu yaklaşıma göre, liderler kendilerine rapor veren bazı üyelere karşı daha yakın, daha dostça, daha kapsayıcı ve daha iletişimseldir. Başka bir deyişle, liderler, ekibinin bir alt kümesiyle yüksek kaliteli, güven, etki ve saygıya dayalı ilişkiler kurmaktadır (Bauer \& Erdoğan, 2016).

Liderler ve takipçiler birbirlerine yakından bağlıdır. Aralarındaki ilişkiyi s1k sık başlatan, iletişim bağlantılarını yaratan ve ilişkiyi sürdürme yükünü taşıyan ise liderdir (Northouse, 2010). Araştırmalara göre bir üyenin kuruluşta kalma kararını etkileyen 
liderin genel davranışları değil, lider ile üye arasında gelişen benzersiz etkileşimdir. Üyeler, kendilerini çok yönlü olarak destekleyen liderler sayesinde organizasyonda çalışmaya devam ettiklerini belirtmektedir (Graen \& Liden, 1982; Çiçek \& Almalı, 2017). Bu nedenle yüksek kaliteli lider-üye etkileşimi, zaman içinde başarılı bir güven oluşturmanın kanıtı olarak görülmektedir (Bauer \& Green, 1996).

Dienesch ve Liden (1986), lider-üye etkileşimini etki, katkı ve bağlılık adını verdikleri üç boyutta ele alıp açıklamıştır. Etki boyutuna göre, liderin ve takipçilerinin beslediği karşılıklı bağlılık duygusu mesleki değerlerden ziyade kişiler arası cazibeye dayandırılmıştır. Bu tip kişiler arası çekim, kişisel bileşenler ve sonuçlar (arkadaşlık gibi) içeren bir ilişki arzusu veya arzunun ötesinde arkadaşlık durumunun ortaya çıkması halinde daha da belirgin bir hale gelebilmektedir (Maslyn \& Uhl-Bien, 2001). Özetle lider ile takipçileri arasındaki etkileşime dikkat çeken bu boyut, bu etkinin liderüye etkileşiminin düzeyini belirleyebileceği varsayımından hareketle ortaya çıkmıştır (Davis \& Gardner, 2004). Katkı boyutu "örgüt içerisindeki ișe dönük faaliyetlerde her üyenin, örgütün açık ve örtülü amaçlarını gerçekleştirmeye yönelik kaliteli hizmet vermesi ve bu amaçlar için resmiyetten uzak, gönülden bir çalışma sergilemesi” olarak tanımlanmıştır (Dienesch \& Liden, 1986: 624). Bağlılık ise takipçilerin ve liderlerin birbirlerine ne kadar sadık olduklarını ifade etmektedir (Gerstner \& Day, 1997) ve "resmi olarak üye ve liderin birbirlerinin eylemlerini ve karakterini alenen ne ölçüde destekledikleri” olarak tanımlanmıştır (Dienesch \& Liden, 1986: 625).

Harika bir iş yeri, insanların çalıştığı insanlara güvendiği, yaptıkları işle gurur duyduğu ve birlikte çalıștıkları insanlardan zevk aldığ $\breve{b i r}$ yerdir. İyi bir lider her iletişiminde, her kararında, her etkileşiminde böyle bir ortamı oluşturabilen ve güçlendiren kişi konumundadır (Burchell \& Robin, 2011). Yapılan araştırmalar göstermektedir ki kurum temsilcileri tarafından çalışanlara yönelik yapılan olumlu ve faydalı yaklaşımlar, yüksek kaliteli ilişkilerin kurulmasına katkıda bulunmaktadır (Dansereau, Graen, \& Haga, 1975). $\mathrm{Bu}$ durumun tersi ise ilişkileri sekteye uğratıp bozulmasına neden olacaktır. Lider üye etkileşimi tek yönlü bir süreç olmadiğ 1 için liderin takipçilerine olan davranışı kadar takipçilerin lidere olan davranışı da oldukça önemlidir. Bu noktadan hareketle çalışmada test edilmek üzere aşağıdaki hipotez oluşturulmuştur.

H2: Işsyeri nezaketsizliği, lider-üye etkileşimi üzerinde negatif bir etkiye sahiptir
Liderler, organizasyonlardaki güncel bir soruna basit bir cevap arayan, var olan realitenin anlaşılmasına ve daha parlak bir gelecek kurulmasına yardımcı olan, yeni firsatları görebilen, bireysel ve kolektif büyümeyi destekleyen karmaşık ve etkileşimli bir süreci yöneten kişi yada kişilerdir (Gallos, 2008). Çalışanlar ise liderle iş arkadaşlarından daha yakın bir ilişki kurarak daha iyi motive olurlar. Bir takımdaki kilit çalışanların liderle daha yakın bir ilişki içinde olduklarını hissetmelerini sağlamak, bu en güvenilir çalışanların performansını en üst düzeye çıkarabilir (Vidyarthi, Liden, Anand, Erdogan \& Ghosh, 2010). Çalışanlara karşı adil olmak, onları daha iyi tanımak yüksek kaliteli bir lider üye etkileşimini beslemektedir. $\mathrm{Bu}$ durum ise gönüllü öğrenme davranıșını arttırmakta ve böylece organizasyonları gelecekteki zorluklar için hazırlamaya yardımcı olmanın yanı sıra, rekabetçi bir avantaj yaratmaktadır (Walumbwa, Cropanzano \& Hartnell, 2009).

Liderlerin en önemli davranışları, ekibin kendini gözlemleme, kendini değerlendirme ve kendi kendini pekiştirme yoluyla kendi kendini yönetmesini kolaylaştırmasıdır (Gupta \& Singh, 2014). Bu durumların toplam çıktısı da örgütlerde yaratıcılığın, inovasyonun ve yaratıcı iş performansının ortaya çıkmasıdır (Tierney, Farmer \& Graen, 1999; Pan, Sun \& Chow, 2012). Bu bağlamda araştırmada test edilmek üzere aşağıdaki hipotez oluşturulmuştur.

H3: Lider-üye etkileşimi, yaratıcı çalışan performansını pozitif yönlü etkiler

Yapılan çalışmalar işyeri (lider/iş arkadaşı) ve işten olmayanların (aile/arkadaşlar) yaratıcılığa açıkça destek verdiğini, çalışanların yaratıcı performanslarına bağımsız katkılarda bulunduğunu ayrıca pozitif ruh halinin yaratıcılığa olumlu ve anlamlı bir katkı yaptığını göstermektedir (Madjar, Oldham, \& Prat, 2002). Çalışanlar örgüt yöneticilerinin davranışlarını yaratıcılı̆̆ destekleyici olarak gördüklerinde, bu davranışları yaratıcılık beklentilerini iletme olarak yorumlama eğiliminde olduklarını göstermektedir. Nitekim en güçlü yaratıcı kapasiteye sahip olduklarını düşünen çalışanlar, amirlerinin rapor ettiği gibi çalışmalarında daha fazla yaratıcılık sergilemektedir (Tierney \& Farmer, 2004). İyi yöneticiler çalışanlarıyla ilgilenenlerdir (Solomon, 1998). Liderler grupların, organizasyonların, bir şirketin ve hatta bir ülkenin kaderinden sorumlu olanlar olarak tanımlanabilir (Sadler, 2003). Bu tanımdan da hareketle liderlerin organizasyonlardaki işleyişin seyrine doğrudan katkıda bulunabilecek potansiyele sahip oldukları savunulabilir. Bundan ötürü işyeri nezaketsizliği ile yaratıcı çalışan performansı 
arasındaki ilişkide lider-üye etkileşiminin önemli bir rol oynayabileceği varsayılmıştır. Buradan hareketle araştırmada test edilmek üzere aşağıdaki hipotez oluşturulmuştur.

H4: Lider-üye etkileşimi, işyeri nezaketsizliği ve yaratıcı çalışan performansı arasındaki ilişkiye aracılı eder

Zhan, Li ve Luo (2019), işyeri nezaketsizliği ile çalışan yaratıcılı̆̆ı arasındaki ilişkide çalışanın yaşının ve çalışma süresinin etkisinin olduğunun altını çizmiştir. $\mathrm{Bu}$ bağlamda kontrol değişkenlerinin (yaş ve mevcut işyerinde çalışma süresi) işyeri nezaketsizliği ile yaratıcı çalışan performansı arasındaki ilişkideki düzenleyicilik etkisinin olabileceği var sayılmıştır. $\mathrm{Bu}$ varsayımı test etmek amacıyla aşağıdaki hipotezler oluşturulmuştur.

H5: Yaş değişkeni, işyeri nezaketsizliği ve yaratıcı çalışan performansı arasındaki ilişkiyi düzenler

H6: Çalışma süresi değişkeni, işyeri nezaketsizliği ve yaratıcı çalışan performansı arasındaki ilişkiyi düzenler

\section{YÖNTEM}

Çalışmada işyerindeki bireylerin maruz kaldığı nezaketsizliğin onların yaratıcı iş performanslarına olan etkisinin ortaya konulması ve bu iki değişken arasındaki ilişkide lider-üye etkileşiminin aracılık etkisinin ortaya konulması amaçlanmıștır. Bu amaç doğrultusunda toplanan verilerin analizinde, teorik ve ampirik çalışmaların istatistiki olarak daha gelişmiş bir zeminde yapılmasını sağlayan (Iacobucci, Saldanha \& Deng 2007) nicel veri analizine dayalı Yapısal Eşitlik Modelinden (YEM) yararlanılmıştır. YEM'in birinci nesil faktör analizi, çoklu regresyon analizi, doğrusal ayrımcılık analizi gibi analizlerin aksine, birden fazla bağıml değişken ile bağımsız değişkenler arasındaki nedensel ilişkiyi aynı anda test edebilen ikinci nesil bir istatistiki yöntem olması ve geleneksel regresyondan daha iyi olduğu için, ölçüm hatalarını dikkate alarak önyargıyı azaltabilmesi (Urbach \& Ahlemann, 2010) gerçeğinden hareketle verilerin analizinde YEM tercih edilmiştir. Ayrıca Iacobucci vd. (2007) YEM yaklaşımlarının tutarlı bir şekilde bir aracılık rolü sonucunu tespit etmede, regresyon yaklaşımından daha güçlü olacağını deneysel olarak kanıtlamıştır. Araştırmada aracılık rolünün analiz edilmesi de YEM'in tercih edilmesinin bir diğer sebebidir. Araştırmada test edilmek üzere oluşturulan model Şekil 2'de verilmiştir.

\subsection{Katılımcilar}

Araştırmaya veri toplamak amacıyla Malatya ilindeki özel sektör ve kamu kesimi çalışanları ve yöneticileri ile bir anket çalışması gerçekleştirilmiştir. Türkiye İstatistik Kurumu (TÜIK) 2013 yılı verilerine göre Malatya'nın toplam istihdam sayıs1 48.910'dur. Cohen, Manion ve Morrison (2002)'a göre örneklem büyüklüğü \%5 hata payı ile 381'dir. TÜİK daha güncel verileri paylaşmadığı için örneklem büyüklüğü bu rakam üzerinden hesaplanmıştır. 2013 yılından itibaren ilin nüfusunda artış olmadığ 1 ve ilin 2013 yılı işsizlik oranları ile günümüz oranları arasında benzerlik olduğu düşünüldüğünde, anakütle büyüklüğünün güncel değerlere oldukça yakın olduğu düşünülmektedir.

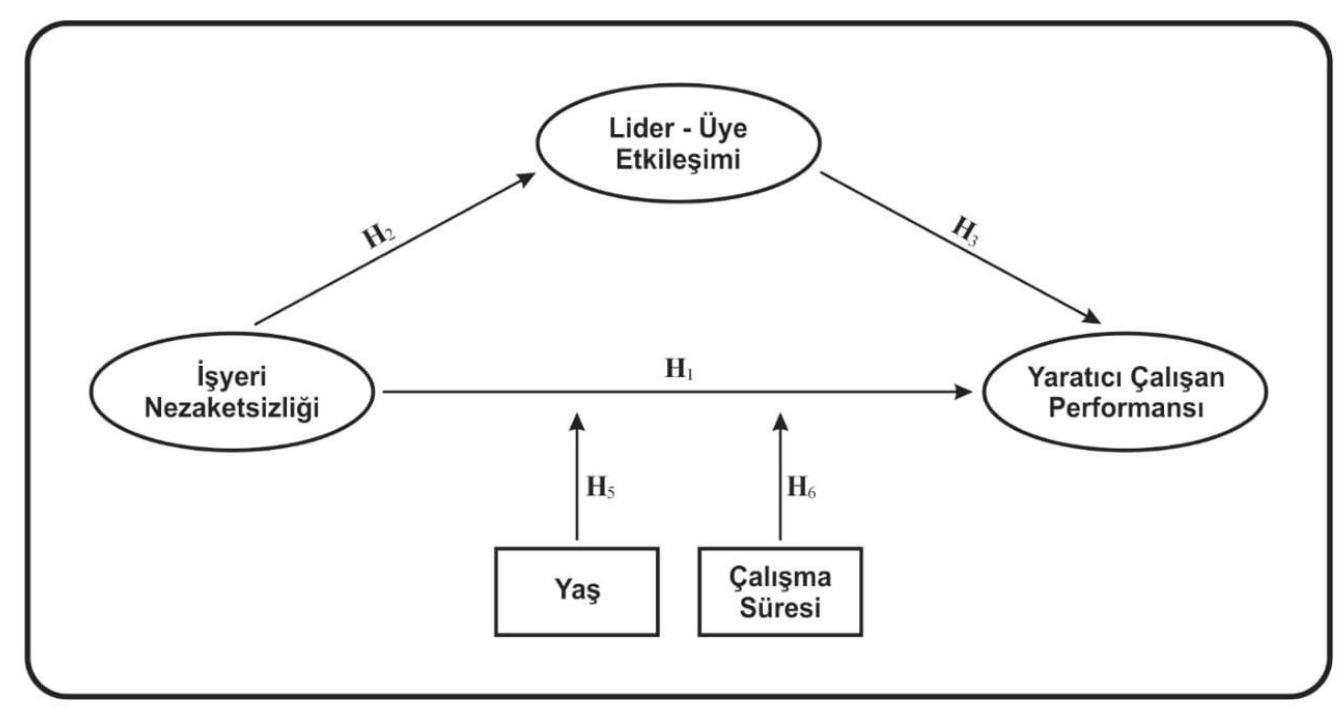

Şekil 2: Araştırmanın Modeli 
Tesadüfi olmayan örnekleme yöntemlerinden olan kolayda örnekleme yöntemine göre seçilen 800 çalışan ve yöneticiye; çalışmanın niteliğini, gizlilik konularını ve katılımın gönüllü olduğunu belirten bir kapak sayfası içeren anket formu Haziran 2019'da online olarak gönderilmiștir. Hazırlanan anket formu Eylül 2019'a kadar cevap verilebilir şekilde bırakılmıştır. Yeterli örneklem sayısına ulaşıldığı düşünüldüğünden form cevaba kapatılıp analizlere geçilmiştir. 800 kişiye iletilen anketlerin toplamda 440'1 cevaplanmıştır. Anketlerin geri dönüş oranı $\% 55$ 'dir. Fakat 20 anket çoğunlukla boş olduğu veya hep aynı seçenek işaretlendiği için değerlendirmeye alınmamıştır. Böylece toplamda 420 çalışan ve yöneticiden gelen anketler analiz yapılmak üzere değerlendirmeye alınmıştır. Örneklem büyüklüğünün 381 olduğu göz önünde bulundurulduğunda, örneklemin ana kütleyi temsil ettiği varsayılmıştır.

Katılımcıların $\mathrm{n}=135{ }^{\prime} \mathrm{i}(\% 32,1)$ kadın, $\mathrm{n}=285^{\prime} \mathrm{i}$ $(\% 67,9)$ erkektir; n=269'u (\%64) kamuda görev yaparken, $\mathrm{n}=151$ ' $\mathrm{i} \quad(\% 36)$ özel sektörde çalışmaktadır; n=334'ü $(\% 79,5)$ çalışan, $n=86$ 's1 $(\% 20,5)$ ise yöneticidir. Katılımcıların yaş ortalaması 35,9 iken mevcut işyerlerinde çalışma süreleri ortalama 7,4 yıldır.

\section{2. Ölçüm Araçları}

Veri toplamak için oluşturulan anket formu dört bölümden oluşmuştur. İlk bölümde katılımcıların demografik bilgilerini öğrenmeye yönelik sorular yer almıştır. İkinci bölümde Cortina, Magley, Williams ve Langhout (2001) tarafindan geliştirilen ve 7 maddeden oluşan işyeri nezaketsizliği ölçeği kullanılmıştır. Literatürde işyeri nezaketsizliğini ölçmek için en sık kullanılan ölçektir. Benzer diğer ölçekler işyeri nezaketsizliğinin yanında işyeri zorbalığı, işyeri suistimali gibi araştırmanın konusu dışında başka boyutları da ölçtüğü için bu ölçek tercih edilmiştir. Ölçeğin giriş kısmına, "İ̧yerinizdeki iş arkadaşlarınız veya yöneticileriniz tarafından aşağıdaki davranışlarla hiç karşılaştınız mı?" tarzında bir açıklama sorusu yazılmıştır. 5'li likert tipinde olan ölçek aralıkları "1- Hiçbir zaman" ve "5- Her zaman" olarak kodlanmıştır.

Anketin üçüncü kısmında lider-üye etkileşimi (LÜE) ölçeği yer almıştır. Ölçek Wayne, Shore ve Liden (1997) tarafından geliştirilen ve birçok diğer çalışmada geçerliliği ve güvenilirliği kanıtlanan 7 maddelik LÜE ölçeğidir. Özellikle LÜE'nin aracı rol olarak değerlendirildiği çalışmalarda tek boyutlu ölçekler tercih edilmektedir. Bu bağlamda ölçeğin temel tercih sebebi LÜE'nin aracı rol olmasıdır. 5'li likert tipindeki ölçeğin aralıkları "1- Hiç katılmiyorum" ve "5- Tamamen kat1lyorum" şeklinde kodlanmıştır.
Anketin son kısmında ise yaratıcı işgören performansını ölçmek için George ve Zhou (2001) tarafından geliştirilen 7 maddelik yaratıcı performans ölçeği kullanılmıştır. Literatürdeki yaratıc1 performans konusunda en önemli çalışmalara imza atan araştırmacıların geliştirdiği ölçek aynı zamanda en yaygın kullanılan ölçektir. 5'li likert tipindeki ölçeğin aralıkları "1- Hiç katılmiyorum" ve "5- Tamamen katıliyorum" şeklinde kodlanmıştır.

Kullanılan ölçeklerin dışında katılımcıların yaşı ve mevcut işyerlerindeki çalışma süreleri kontrol değişken olarak kullanılmıştır. Ölçekler paralel kör teknik kullanılarak (Brislin, 1980) Türkçeye çevrildikten sonra bir pilot uygulamaya tabi tutulmuştur. Ölçeklerin anlaşılabilirliği geçerliliği ve güvenirliğiyle ilgili problem olmadığına kanaat getirildikten sonra nihai uygulamaya geçilmiş̧ir.

Anket yöntemiyle toplanan veriler tüm çalışan ve yöneticilerden aynı anda toplandığı için ortak yöntem varyansının (common method variance) problem yaratabileceği göz önünde bulundurulmuştur. Ortak yöntem varyansını test etmek için öncelikle Harman'ın (1967) tek-faktör (single-factor) testi uygulanmıştır. Buna göre döndürme yöntemi uygulamadan tüm maddeler tek faktör altında incelenmiştir. Oluşturulan bu faktör tarafından açıklanan varyans miktarı \%34,4'dür. Kline, (2005) bu değerin \%50'nin altında olması gerektiğini belirtmiştir. Çalışmada ölçülen değer \%50'nin altında olduğu için ortak yöntem hatası olmadığı sonucuna ulaşılmıştır. Daha sonra gözlemlenen tüm öğelerin kendisiyle ilişkili olacak şekilde yeni bir gizli ortak değişken faktörü eklemekten oluşan Ortak Gizil Faktör (Common Latent Factor CLF) yöntemi kullanılmıştır. Yeni ortak gizli faktörün eklenmesinin, modeldeki uyum indekslerini önemli ölçüde iyileștirmemesi durumunda ortak yöntem varyansı bir problem olarak kabul edilemez. Modelimize CLF gizli değişkenini yerleştirdikten sonra uyum indekslerinde herhangi bir değişiklik olmadığ gözlemlenmiştir, ayrıca CLF'nin her bir gözlenen değişkene giden yolunun faktör değerinin 0 olduğu görülmüştür, bu durum modelde ortak yöntem hatasının olmadığını göstermektedir (Eichhorn, 2014).

\subsection{Geçerlilik ve Güvenilirlik Analizleri}

Kullanılan ölçekler Türkçe olarak ilk kez uygulandığ1 için yapı geçerliliklerini test etmek amaciyla SPSS v25 programı ile öncelikle açımlayıcı faktör analizine (AFA) tabi tutulmuştur. Ölçeklerin faktör analizine uygunluğunu tespit etmek için KMO ve Bartlett testi yapılmıştır. KMO değerinin ,921 olduğu görülmüştür. Bartlett 
Tablo 1: Açımlayıcı Faktör Analizi Bulguları

\begin{tabular}{|c|c|c|c|c|}
\hline & 1 & 2 & 3 & Varyans \\
\hline \multicolumn{5}{|l|}{ İşyeri Nezaketsizliği } \\
\hline 1- Aşağılanıp, küçümsendiniz mi? & & & ,717 & \multirow[t]{7}{*}{39,525} \\
\hline $\begin{array}{l}\text { 2- İfadelerinize çok az dikkat edildiği veya fikirlerinize ilgi gösterilmediği } \\
\text { oldu mu? }\end{array}$ & & & ,599 & \\
\hline 3- Hakkınızda aşağılayıcı veya küçük düşürücü açıklamalar yapıldı mı? & & & 818 & \\
\hline $\begin{array}{l}\text { 4- Herkesin içerisinde veya özel alanlarda profesyonel sayılmayacak } \\
\text { terimlerle hitap edildi mi? }\end{array}$ & & & ,644 & \\
\hline $\begin{array}{l}\text { 5- Görmezden gelindiğiniz veya iş arkadaşları ekibinizden dışlandığınız oldu } \\
\text { mu? }\end{array}$ & & &, 840 & \\
\hline $\begin{array}{l}\text { 6- Sorumluluğunuzda olan bir konuyla ilgili görüşünüze şüpheyle yaklaşıldı } \\
\text { mı? }\end{array}$ & & &, 816 & \\
\hline $\begin{array}{l}\text { 7- Sizi bir tartışmaya veya kişisel meseleye çekmek için istenmeyen } \\
\text { girişimlerde bulunuldu mu? }\end{array}$ & & & ,739 & \\
\hline \multicolumn{5}{|l|}{ Lider-Üye Etkileşimi } \\
\hline 1- Yöneticime karşı konumumu genellikle bilirim. & & ,353 & & \multirow[t]{7}{*}{17,072} \\
\hline 2- Yöneticim, ben olmasam dahi kararlarımı savunacak kadar bana güvenir. & & ,709 & & \\
\hline 3- Yöneticimle etkili bir iş ilişkisine sahibiz. & & 857 & & \\
\hline 4- Yöneticim sorunlarımı ve ihtiyaçlarımı anlar. & & 873 & & \\
\hline $\begin{array}{l}\text { 5- Gerçekten ihtiyacım olduğu takdirde, yöneticimin kendi zararı pahasına } \\
\text { beni zor durumdan kurtaracağına inanıyorum. }\end{array}$ & & ,873 & & \\
\hline 6- Yöneticim potansiyelimi bilir. & & 672 & & \\
\hline $\begin{array}{l}\text { 7-Yöneticim, pozisyonunun gücünden bağımsız olarak, işimdeki } \\
\text { problemlerimi çözmem konusunda bana kişisel olarak yardımcı olmaya } \\
\text { isteklidir. }\end{array}$ & & ,945 & & \\
\hline \multicolumn{5}{|l|}{ Yaratıcı Çalışan Performansı } \\
\hline 1- Amaç ve hedefleri gerçekleştirmek üzere yeni yollar öneririm. & ,806 & & & \multirow[t]{7}{*}{8,872} \\
\hline 2- Performansı iyileştirmek için yeni ve kullanışlı fikirler üretirim. & ,925 & & & \\
\hline 3- Kaliteyi artırmak için yeni yollar öneririm. & 900 & & & \\
\hline 4- Yaratıcı fikirler için iyi bir kaynağım. & ,808 & & & \\
\hline 5- Fırsat verildiğinde işimde yaratıcılık sergilerim. & ,866 & & & \\
\hline 6- Sıklıkla yeni ve inovatif fikirlerim vardır. & 879 & & & \\
\hline 7- Sıklıkla problemlere karşı taze yaklaşımlarım vardır. & 865 & & & \\
\hline $\begin{array}{l}\text { Toplam Varyans: \%65,47; Tekrarlama Sayısı: 4; Döndürme Yöntemi: } \mathbf{P} \\
\text { Bartlett Küresellik Testi: 7180,651(210), Anlamlılık: p =,000; Goodness of }\end{array}$ & $\begin{array}{l}\max \\
: \chi^{2}=\end{array}$ & M & & : 0.921; \\
\hline
\end{tabular}

değerinin ise $\chi^{2}=7180,651(210) ; p=, 000<0,05$ bulunmuştur. Literatürde KMO testi ölçüm sonucunun 0.50 ve daha üstü, Bartlett küresellik testi sonucunun da istatistiksel olarak anlamlı olması gerekmektedir (Tavşancıl, 2002). Elde edilen sonuçlara göre kullanılan ölçeklerin AFA'ya uygun olduğu görülmüştür. Yapılan AFA sonuçları Tablo 1'de verilmiştir.

Tablo 1'den de görüleceği üzere yapılan AFA sonucunda 3 faktörlü bir yapı oluşmuştur. Tüm ifadeler kendi ölçeği içerisinde yerini aldığ 1 için faktör yapısının uygun olduğuna ve Türkçe çevirisinde sorun olmadığına kanaat getirilmiştir.
Anderson ve Gerbing (1988) yapısal eșitlik modellemesinin iki aşamalı olarak test edilmesi gerektiğini belirtmiştir. Buna göre ilk aşamada bir ölçüm modeli kurularak yapı geçerliliğinin test edilmesini, ikinci aşamada ise yapısal modelin test edilmesini önermiştir. AMOS v26 programı ile maximum likelihood modunda kurulan ölçüm modelinin iyilik uyum indekslerinin kabul edilebilir sinırlar içerisinde (Hu \& Bentler, 1999; Sivo, Fan, Witta \& Willse, 2006) olduğu görülmüștür $(\chi 2 / \mathrm{df}=$ 3.106 , RMSEA $=0.076$, GFI $=0.940$, AGFI $=$ $0.938, \mathrm{TLI}=0.957, \mathrm{CFI}=0.963$ ). Ölçeklere ilişkin uyuşum ve ayırt edici geçerlilik ile tanımlayıcı istatistiklere ilişkin veriler Tablo 2'de verilmiştir.

Tablo 2: Tanımlayıcı İstatistikler

\begin{tabular}{lcccccccc}
\hline & Ort. & SS & CR & AVE & MSV & 1 & 2 & 3 \\
\hline 1. İşyeri Nezaketsizliği & 1,98 &, 89 & 0,896 & 0,555 & 0,325 & - & & \\
\hline 2. Lider-Üye Etkileşimi & 3,44 & 1,15 & 0,916 & 0,618 & 0,325 &,$- 570 * * *$ & - & \\
\hline 3. Yaratıcı Çalışan Performansı & 4,08 &, 86 & 0,953 & 0,742 & 0,150 &,$- 388^{* * *}$ &, $314^{* * *}$ & - \\
\hline
\end{tabular}


Fornell ve Larcker (1981) ise yapisal modelde anlamlı bir ilişki için test yapmadan önce, ölçüm modelinin yeterli düzeyde bir geçerlilik ve güvenilirliğe sahip olduğunun kanıtlanması gerektiğini savunmuştur. Bunun için ölçeklerin uyuşum ve ayırt edici geçerliliği sağlaması ve iyi uyum değerlerine sahip olması, ayrıca Cronbach's $\alpha$ değerinin kabul edilebilir sınırlar içerisinde olması beklenmektedir. Ölçeklerin uyuşum geçerliliğini sağlaması için tüm faktör yüklerinin 0,50 eşiğinden önemli ölçüde fazla olması (Fornell \& Larcker, 1981), maddelerde kendi yapılarıyla çıkarılan ortalama varyansın (AVE) açıklanamayan varyanstan (AVE $>0.50)$ büyük olması (Bagozzi \& $\mathrm{Yi}, 1988$ ) ve faktör kompozit güvenilirliğinin (CR) 0,60 'a eşit veya daha büyük olması gerekmektedir (Fornell \& Larcker, 1981).

Tablo 1'de görüleceği üzere lider-üye etkileşimi ölçeğinin ilk maddesinin faktör değeri 0,50'nin altındadır. Bu nedenle bu madde ölçüm modelinden çıkarılmıştır. Böylece kalan maddelerle tekrarlanan analizde tüm AVE değerleri 0.500 eşiğinin üzerine çıkmış ve uyuşum geçerliliği sağlanmıştır. Ayırt edici geçerlilik için çıkarılan varyans tahmin değerlerinin (AVE) korelasyon değerlerini geçmesi gerekmektedir (Fornell \& Larcker, 1981; Hair, Black, Babin, Anderson, \& Tatham, 2006). Tablodan da anlaşılacağı üzere değişkenlerin AVE değerleri korelasyon değerlerini aşmaktadır. İkinci koşul olarak AVE değerlerinin MSV değerlerini aşması beklenmektedir. Değişkenler arasında bu koşul da sağlandığından ötürü ayırt edici geçerliliğin de sağlandığı görülmüştür. Bununla birlikte Henseler, Ringle ve Sarstedt (2015) ayırt edici geçerliliği test etmek için korelasyonların heterotrait-monotrait oranının (HTMT) hesaplanmasını önermiştir. $\mathrm{Bu}$ değerin 0.85 'den düşük olması gerekmektedir. Yapılan analizlerde HTMT değerlerini 0.85 'den oldukça düşük olduğu tespit edilmiştir (Sırasıyla; ,606; ,384; ,384). Bu sonuçlara göre ölçeklerin yapı geçerliliği açısından herhangi bir problemi olmadığı ve oldukça iyi bir geçerliliğe sahip olduğu belirlenmiştir. Araştırmanın güvenilirliğini, normalliğini ve çoklu bağlantı sorununun olup olmadığını test etmeye yönelik yapılan analizlerin sonuçları Tablo 3'de verilmiștir.
Kovaryans temelli yapısal eşitlik modellemesi yapabilmek için ön koşullardan biri olarak dağılımın normalliği gösterilmektedir. Normalliği test etmek için ortalaması alınan değişkenlerin çarpıklık ve basıklıkları kontrol edilmiştir (tablodaki çarpıklık ve basıklık değerleri en yüksek olan maddeye aittir). Değerler $+1,5$ ve $-1,5$ sınırını aşmadığı için dağılım normal kabul edilmiştir (Tabachnick, Fidell, \& Ullman 2007). Daha sonra çoklu bağlantı sorunu olup olmadığına bakılmıştır. Değişkenler arasındaki doğrusal regresyon analizi ile elde edilen VIF değerleri literatürde sıkça kabul gören 5 değerinin oldukça altında olduğu için çoklu bağlantı sorunu olmadığı görülmüştür (Craney \& Surles, 2002). Son olarak değişkenlerin cronbach's $\alpha$ değerlerine bakılmıştır ve ölçeklerin oldukça güvenilir olduğu görülmüştür (Zinbarg, Revelle, Yovel, \& Li, 2005). Tüm bu analizler sonucunda ölçeklerin geçerliliği ve güvenilirliği kanıtlanmıştır ve yapısal modele geçilmiştir.

\section{Yapısal Eşitlik Analizi}

Çalışmada işyeri nezaketsizliğinin yaratıcı çalışan performansı üzerindeki etkisi ve bu ilişkide liderüye etkileşiminin rolünün ortaya konulması amaçlanmıştır. Bu bağlamda oluşturulan hipotezleri test etmek amaciyla yapısal eșitlik modeli kurulmuştur. Model, AMOS v26 programiyla maximum likelihood modunda test edilmiştir. Kurulan modelde doğrudan ve aracı model üzerinden açıklanan dolaylı ilişkiler test edilmiştir. Baron ve Kenny (1986) yaptıkları çalışmada aracı değişkeni; bağımsız değişken ile bağımlı değişken arasındaki etkinin üretkenliği şeklinde tanımlamıştır. Ayrıca aracılık etkisi üç koşula bağlamıştır. Buna göre, birinci koşul bağımsız değişkenin bağımlı değişkeni etkilemesi, ikinci koşul bağımsız değişkenin aracı değişkenler üzerinde bir etkisinin olması, üçüncü koşul aracı değişkenin bağımlı değișkeni etkilemesidir. Tüm bu koşulların sağlanması durumunda; aracı etki modele girdiği takdirde bağımlı değişken ile bağımsız değişken arasındaki ilişki azalıyorsa kısmi, bağımlı değişken ile bağımsız değişken arasındaki ilişki anlamsızlaşıyorsa tam aracılığın olduğunu savunmuşlardır. $\mathrm{Bu}$ yaklaşım iyi sonuçlar vermektedir ancak Sobel testinde olduğu gibi tek bir p-değeri vermemektedir ayrıca dolaylı etki için bir güven aralığı da yaratmamaktadır (Falk, 2017). Bu

Tablo 3: Normallik, Doğrudaşlık, Güvenilirlik Analizi Sonuçları

\begin{tabular}{lccccc}
\hline \multicolumn{1}{c}{ Değişkenler } & Çarpıklık & Basıklık & Tolerance & VIF & Alpha \\
\hline İşyeri Nezaketsizliği & 1,250 & 1,136 &, 692 & 1,445 &, 893 \\
\hline Lider-Üye Etkileşimi &,- 414 &,- 839 &, 719 & 1,390 &, 930 \\
\hline Yaratıcı İş Performansı & $-1,362$ & 1,474 &, 858 & 1,166 &, 952 \\
\hline
\end{tabular}


Tablo 4: Doğrudan İlişki Analizi Sonuçlanı

\begin{tabular}{lclrrrr}
\hline & & & Estimate $^{\mathbf{1}}$ & S.E. & C.R. & P \\
\hline LÜE & $\leftarrow$ & İşyeri_Nezaketsizliği &,- 564 &, 064 & $-9,864$ & $* * *$ \\
\hline Yaratıcı_Performans & $\leftarrow$ & İşyeri_Nezaketsizliği &,- 320 &, 059 & $-5,093$ & $* * *$ \\
\hline Yaratıcı_Performans & $\leftarrow$ & LÜE &, 125 &, 050 & 2,102 &, 036 \\
\hline Yaratıcı_Performans & $\leftarrow$ & Yaş &,- 081 &, 005 & $-1,769$ &, 077 \\
\hline Yaratıcı_Performans & $\leftarrow$ & ÇalSür &, 115 &, 050 & 2,102 &, 036 \\
\hline 'Standadize edilmiş katsayllar verilmiştir; ***p<0.001. & & & \\
\hline
\end{tabular}

nedenle Mallinckrodt, Abraham, Wei ve Russell (2006) çalışmalarında deneysel araştırmalarda bootstrap analizlerinin kitle parametresine ilişkin güven aralığının hesaplanmasının faydalı olduğunu belirtmişlerdir. Efron ve Tibshirani (1986) ise bootstrap metodunu; standart sapma, güven aralığ 1 gibi istatistiklerde ve parametrik olmayan tahminleme problemlerinde yeniden örnekleme için kullanılan basit ve güvenilir bir metot olarak tanımlamıştır. Mallinckrodt vd., (2006) bootstrap örnekleminin 1000'den az olmaması koşulunun daha rasyonel bir fikir olacağını da ayrıca belirtmişlerdir (Burmaoğlu, Polat, \& Meydan 2013). Bu nedenle arac1 etkinin analizinde Baron ve Kenny'nin (1986) önerdiği adımlar, bootstrap metoduyla test edilmiştir. Bootstrap örneklemi ise 5000 olarak belirlenmiştir.

Kurulan modelin uyum indeksleri $\chi 2 / \mathrm{df}=3.181$, RMSEA $=0.074$, GFI $=0.928$, AGFI $=0.934$, TLI $=0.948, \mathrm{CFI}=0.951$ olarak ölçülmüştür. $\mathrm{Bu}$ değerler göz önünde bulundurulduğunda modelin kabul edilebilir uyum değerlerine sahip olduğu görülmüştür (Hu \& Bentler, 1999; Sivo vd., 2006). Kurulan modeldeki doğrudan ilişki analizleri Tablo 4'de verilmiştir.

Modeldeki ilişkiler incelendiğinde; işyeri nezaketsizliğinin lider üye etkileşimi $(\beta=-, 564$; $p<0,001)$ ve yaratic1 performans $(\beta=-, 320 ; p<0,001)$ üzerinde negatif yönlü ve anlamlı bir etkiye sahip olduğu görülmüştür. Lider üye etkileşiminin yaratıc1 performans üzerinde $(\beta=, 125 ; p<0,001)$ pozitif yönlü ve anlamlı bir etkisi vardır. Araştırmanın bu sonuçlarına göre $\mathrm{H} 1, \mathrm{H} 2$ ve $\mathrm{H} 3$ hipotezleri desteklenmiştir. Ayrıca modelde test edilen kontrol değişkenlerden yaşın yaratıcı performans üzerinde $(\beta=-, 081, p>0,05)$ anlamlı bir etkiye sahip olmadığı, çalışma süresinin ise $(\beta=, 115, p<0,05)$ pozitif yönlü ve anlamlı bir etkiye sahip olduğu görülmüştür. $\mathrm{Bu}$ sonuçlara göre $\mathrm{H} 5$ hipotezinin ön koşulu sağlanamadığ 1 için reddedilmiştir. Araştırmada test edilen dolaylı ilişki analizinin sonuçları Tablo 5'de verilmiştir.

H4 hipotezi işyeri nezaketsizliği ile yaratıcı performans arasındaki ilişkide lider-üye etkileşiminin aracılık rolüne sahip olduğunu öngörmekteydi. Tablodan da anlaşılacağı üzere işyeri nezaketsizliği ile yaratıcı performans arasındaki ilișki aracı değișken eklenmeden önce $(\beta=-, 320, p<0.001)$ anlamlıdır. İkinci aşamada aracı değişken olan lider-üye etkileşimi değişkeni modele eklendiğinde işyeri nezaketsizliği ile yaratıcı performans arasındaki ilişki $(\beta=-, 081, \quad p>0.05)$ azalarak anlamsızlaşmaktadır. Ayrıca bootstrap yöntemiyle test edilen modelde lider-üye etkileşiminin eklendiği modelin anlamlı bir dolaylı etkiye sahip olduğu da $(\beta=-, 271, \quad p<0.001)$ görülmüştür. $\mathrm{Bu}$ sonuçlarla lider-üye etkileşiminin işyeri nezaketsizliği ile yaratıcı performans arasındaki ilişkiye tam aracılık ettiği doğrulanmış ve H4 hipotezi kabul edilmiştir.

H6 hipotezi işyerindeki çalışma süresinin işyeri nezaketsizliği ile yaratıcı iş performansı arasındaki ilişkiyi düzenleyeceğini öngörmektedir. Düzenleyici değişken, bağımsız değişkenle bağımlı değişken arasındaki ilişkinin etki gücünü ve yönünü etkileyen bir değişkendir (Baron \& Kenny, 1986). $\mathrm{Bu}$ ilişkiyi test etmek amacıyla öncelikle değişkenlerin merkezlenmiş ortalaması (mean centered - zcore) alınmıştır. Daha sonra etkileşim terimi olușturularak hiyerarşik regresyon analizi yapılmıştır. Hiyerarşik regresyon analizinin ilk aşamasında bağımsız değişkenin (işyeri

Tablo 5: Dolaylı İlişki Analizi Sonuçlanı

\begin{tabular}{lcccc}
\hline Hipotez & Doğrudan & Doğrudan & Dolaylı Etki & Aracılık Durumu \\
& $\mathbf{E t k i}^{1}$ & $\mathbf{E t k i}^{\mathbf{2}}$ & $\boldsymbol{\beta}$ & \\
\hline $\mathbf{H}_{\mathbf{4}}:$ İN $\rightarrow$ LÜE $\rightarrow$ YP & $\boldsymbol{\beta}$ & $\boldsymbol{\beta}$ & & \\
\hline${ }^{1}$ Aracı Değişken Eklenmeden Önce; ${ }^{2}$ Aracı Değişken Eklendikten Sonra; ${ }^{3}$ ns $($ not significant) $=$ anlamlı değil; \\
*** $<0.001$
\end{tabular}




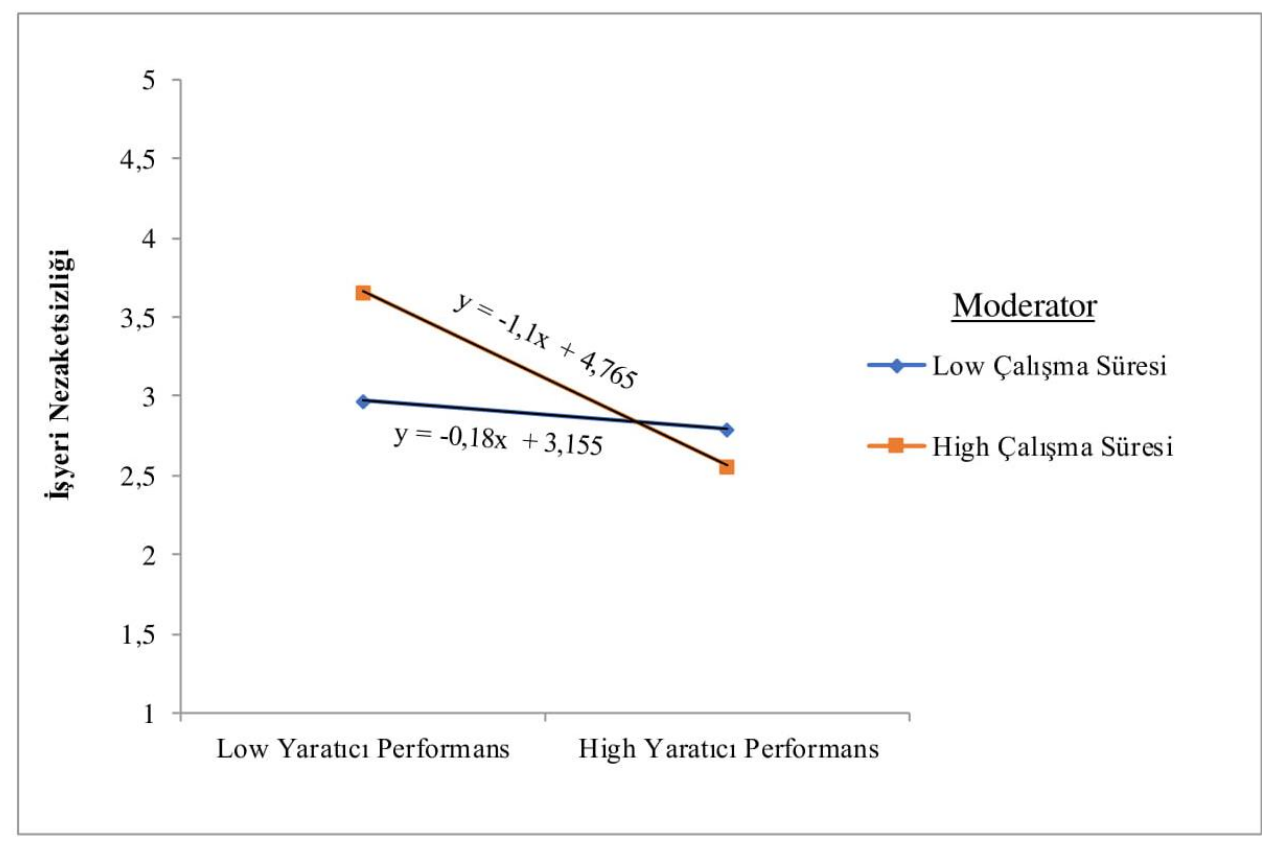

Şekil 3: Düzenleyici Etki Analizi Slope Matrisi

nezaketsizliği) bağımlı değişken (yaratıcı çalışan performansı) üzerindeki etkisi, ikinci aşamasında bağımsız ve düzenleyici (çalışma süresi) değişkenin bağımlı değişken üzerindeki etkisi, üçüncü aşamasında ise bağımsız, düzenleyici değişken ve etkileşim değişkeninin aynı anda bağımlı değişken üzerindeki etkisi analiz edilmiştir.

SPSS v25 programı ve Process Macro 3.3 (Hayes, 2017) eklentisiyle yapılan analizlerin sonucuna göre çalışma süresi (İNXÇalSür, $\beta=-, 230, p<0.05$ ) işyeri nezaketsizliği ile yaratıcı çalışan performansı arasındaki negatif ilişkiyi düzenlemektedir. ilişkinin yönüyle ilgili daha detaylı inceleme yapmak için Cohen, West ve Aiken (2014) tarafindan önerilen süreç izlenmiştir. $\mathrm{Bu}$ doğrultuda, değişkenler arasındaki ilişkinin anlamlılığını ayrıntılı bir şekilde görebilmek için regresyon eğrisi çizilmiş ve Aiken, West ve Reno (1991) tarafından önerilen Slope test analiz yöntemi uygulanmıştır. Çizilen regresyon eğrisi Şekil 3'de verilmiştir.

Şekil 3'te görüldüğü üzere, doğruların paralel olmaması düzenleyici etkinin varlığını kanıtlamaktadır. Buna göre çalışma süresi, işyeri nezaketsizliği ile yaratıcı performans arasındaki negatif yönlü ilişkiyi artırmaktadır. Çalışma süresi düşük $(\beta=-, 018, p>0.05)$ ve orta $(\beta=-, 076, p>0.05)$ olduğu durumlarda anlamsız iken yüksek olduğu durumda $(\beta=-, 281, p<0.01)$ negatif ve anlamlı bir etkiye sahiptir. Buna göre bireylerin çalışma süresi arttıkça işyeri nezaketsizliğinin yaratıcı performans üzerindeki negatif etkisi de artmaktadır. Bu sonuçlara göre H6 hipotezi kabul edilmiştir.

\section{SONUÇ VE TARTIŞMA}

Son y1llarda çeşitli sektörlerde yapılan araştırmalar, işyerlerindeki nezaketsiz davranışların çalışanlar arasındaki ilişkileri sekteye uğratabileceğini bu durumun da çalışanların ve işletmelerin ortaya koyacağı çıktılar üzerinde olumsuz etkilere sebep olabileceğini göstermiştir (Cortina \& Magley, 2009; Sakurai \& Jex, 2012; Sliter, Pui, Sliter, \& Jex, 2011). $\mathrm{Bu}$ çalışmada işyeri nezaketsizliğinin yaratıcı çalışan performansı üzerindeki etkisi ve bu ikisi arasındaki ilişkide lider-üye etkileşiminin aracı; yaş ve çalışma süresinin ise düzenleyici etkisinin ortaya konulması amaçlanmıştır. Bu amaç doğrultusunda literatür taramasıyla oluşturulan hipotezleri test etmek amaciyla nicel bir araştırma yapılmıştır. Araştırmaya veri toplamak için Malatya ilindeki özel sektör ve kamu kesimi çalışanları ile bir anket çalışması gerçekleştirilmiştir. Yapısal eşitlik modellemesi ile oluşturulan araştırma modelinin analizinin sonucunda, işyeri nezaketsizliğinin yaratıcı çalışan performansı üzerinde negatif yönlü bir etkiye sahip olduğu görülmüştür. Çalışmanın bu bulgusu Zhan, Li ve Luo'nun (2019), Hur, Moon ve Jun'un (2016), Porath, Foulk ve Erez'in (2015) çalışmaları ile paralellik göstermektedir.

Araştırmada, işyeri nezaketsizliğinin lider-üye etkileşimi üzerinde de negatif bir etkiye sahip olduğu görülmüştür. Bu durum Thompson, Buch ve Glasø’nun (2018) çalışmasıyla benzerlik göstermektedir. İşyerindeki nezaketsiz davranışlar 
şüphesiz lider ve takipçileri arasındaki etkileşimi etkileyebilmektedir. Çalışanların nezaketsiz davranışları liderin iletişim süreci içerisindeki çabalarını tıkayabileceği gibi, liderin nezaketsiz davranışlarının çalışanları, sinikleştirmeye, sessizleştirmeye, düşük performans sergilemeye ve hatta işten ayrılmaya kadar itebilecektir.

Waples ve Friedrich'e (2011) göre performans yönetimi, bir kuruluşun işgücünün liderlerin ortaya koyduğu hedeflere ulaşmasını sağlamak için temel bir uygulamadır. Liderler, bulundukları organizasyondaki takipçilerinin görev performansını iyileştirdiği gibi problem çözmeyi kolaylaştırır ve diğerlerinin psikolojik iyi oluşlarını etkilemeye yönelik davranışlar sergilerler (Çiçek \& Deniz, 2017). Ayrica Dul ve Ceylan (2011), çalışanların yaratıcılı̆̆ını organizasyonun her kademesinde geliştiren çalışma ortamları tasarlayarak ergonominin yenilikçiliğe katkıda bulunabileceğini önermektedir. Araştırmada liderüye etkileşiminin yaratıcı çalışan performansı üzerinde pozitif bir etkiye sahip olduğunun görülmesi yukarıdaki yargıları desteklemiştir. Liderin organizasyon içerisinde yerine getirdiği önemli fonksiyonlardan birinin takipçilerinin yaratıcılığını tetiklemek olduğu göz önünde bulundurulduğunda, aslında bu beklenen bir sonuçtur.

Araştırmanın bir diğer bulgusu, işyeri nezaketsizliği ile yaratıcı çalışan performansı arasındaki ilişkiye lider-üye etkileşiminin aracılık ettiğidir. Başka bir deyişle nezaketsizlik davranışı her ne kadar çalışanın yaratıcılığını olumsuz etkilese de lider ve takipçileri arasındaki başarılı etkileşim bu olumsuzluğa bir son verebilmektedir. Organizasyonlar açısından düşünüldüğünde, her çalışanın nasıl davranması gerektiğini, tarzını, kişiliğini değiştirmek pek mümkün değildir. Fakat olas1 bir olumsuz durumda insanların performanslarının hemen etkilenip, çıktıların düşmesinin önüne geçebilecek bir unsur olarak liderlik göz önünde bulundurulmalıdır. Lider birçok olumsuzluğu, çatışmayı vb. yönetebildiği gibi işyerindeki nezaketsizliği de iyi yöneterek bu durumun üstesinden gelebilecek potansiyele sahiptir.

Çalışmada işyeri nezaketsizliği ile yaratıcı çalışan performansı arasındaki ilişkiye bireyin yaşının ve mevcut işyerindeki çalışma süresinin etkisi de analiz edilmiştir. Buna göre bireyin yaşı bu ilişkinin seyrine bir etkide bulunmamaktadır. Fakat bireylerin mevcut işyerlerindeki çalışma süreleri arttıkça, nezaketsiz davranışların onları daha çok etkilediği ve yaratıcılıklarını daha fazla öldürdüğ̈̈ sonucuna ulaşılmıştır.
Günümüz toplum yapıs1, özellikle kitle iletişim araçlarında verilen ve dünyanın hemen her kültüründen enformasyon çeşitliğinin artışı ve insanların birçoğunun bunları algılayışındaki farklılıkları bir arada bulundurmak zorunda olan insanlar için, anlaşma ve uyuşma yönüyle sıkıntılar yaratabilmektedir. Özellikle bir işyerinde farklı düşüncedeki insanların bir arada bulunma zorunluluğu beraberinde anlaşmazlıkları hatta çatışmaları getirebilmektedir. $\mathrm{Bu}$ durum organizasyonların işleyişini ve performansını düşürebilmektedir. $\mathrm{Bu}$ nedenle bireyler arasındaki ilişkilerin iyi bir şekilde yönetilmesi gerekmektedir. Burada liderlik kilit kavram olarak karşımıza çıkmaktadır. Liderin organizasyona bu yönde mutlak suretle olumlu bir katk1 sunabileceği bu çalışmada ampirik olarak da kanıtlanmıştır.

Yapılan araştırmada kamu kesimi ile özel sektör çalışanları arasında davranışlar ve çıktılar açısından herhangi bir farklılık olmadığı görülmüştür. İlk bakışta bu bulgu şaşırtıcı bir sonuç gibi görünse de aslinda beklenen bir durumdur. Gerek kamuda gerekse de özel sektörde olsun, çalışanlar işyerinde nezaketsizliğe uğradığında bu durum yaratıcı performansları üzerinde olumsuz bir etkiye neden olmaktadır. Ayrıca her iki sektörde de lider-üye etkileşiminin kalitesinin artması nezaketsizliğin olumsuz çıktılarını azaltabilmektedir. Sonuçta burada etkilenen insan psikolojisi ve davranışı olduğu için bu duruma sektörün etki etmemesi oldukça olağan bir durumdur.

Çalışma neticesinde birtakım öneriler de sunulmaktadır. Buna göre;

- $\quad$ Nezaketsizlik sarmalı düşünüldüğünde (Anderson \& Pearson, 1999) nezaketsizliği kim başlatırsa başlatsın, nezaket dışı davranış her iki tarafa da bulaşmakta ve aynı oranda zarar verebilmektedir. $\mathrm{Bu}$ nedenle organizasyon içerisinde hangi kademede olursa olsun nezaketsiz davranışlardan kaçınmak gerekmektedir.

- Tüketicilerin farklı ve benzersiz ihtiyaçlara sahip olduğu günümüz dinamik pazar yapısında ister kamu kuruluşu ister özel işletmelerin, hizmet sunumu sürecinde belirli kurallara değil, yenilikçi ve uyarlanabilir davranışlara odaklanması önerilebilir.

- $\quad$ Lider organizasyonda birçok işlevi yerine getirebilecek bir fonksiyona sahiptir. Liderin takipçileri ile olan etkileşimi de örgütsel açıdan oldukça faydalı çıktılar sunabilmektedir. Buradan hareketle yaratıcılığı artırmak için lider-üye etkileşiminin güçlendirilmesi gerektiği önerilebilir. 
Bu araştırmanın bazı kısıtlılıkları da bulunmaktadır. Çalışanların kendilerine karşı nezaketsizliği ölçmeye yönelik ölçeğe zaman zaman dürüst cevaplar vermekten kaçınmış olabilecekleri göz önünde bulundurulmalıdır. Her ne kadar gizlilik ve üçüncü kişilerle paylaşılmadığı beyan edilse de bu durum bir sinırlılık olarak değerlendirilmelidir. Ayrıca kamu ve özel sektördeki kurumsal firmalardan verilerin toplanmış olması, çoğu çalışanın günlük işleyiş içerisinde pek fazla nezaketsizliğe maruz kalmadığı bir örneklemle çalışmaya neden olmuştur. Bu durum da başka bir kısıt olarak değerlendirilmiştir.

Gelecek çalışmalara özellikle yukarıda bahsedilen sınırlılıkları giderebilecek bir örneklem üzerine yoğunlaşmaları önerilebilir. Ayrıca paternalistik ve otantik liderlik tarzlarının da işyeri nezaketsizliği ile çalışan yaratıcı performansı arasındaki ilişkiye aracılık edeceği düşünülmektedir. Ayrıca nezaketsizliğin işten ayrılma niyeti ile sonuçlanabileceği de düşünülmektedir. Gelecek çalışmaların bu değişkenlerin nedensel ilişkileri üzerine yoğunlaşmaları önerilebilir.

\section{ETIK BEYANATI}

Destek Bilgisi: Bu çalışma kamu, ticari veya kâr amacı gütmeyen kuruluşlar gibi herhangi bir organizasyondan destek almamıştır.

Çıkar Çatışması: Tüm yazarlar adına, sorumlu yazar çıkar çatışması olmadığını belirtir.

Etik Onayı: İnsan katılımcıları içeren çalışmalarda gerçekleştirilen tüm prosedürler, kurumsal ve/veya ulusal araştırma komitesinin etik standartlarına ve 1964 Helsinki deklarasyonuna ve daha sonraki değişikliklerine veya karşılaştırılabilir etik standartlara uygundur.

Bilgilendirilmiş Onam Formu: Çalışmaya katılan tüm bireyler, araștırmanın içeriği konusunda ve çalışmanın gönüllük esasına göre yürütüldüğüne dair bilgilendirilmiştir.

\section{KAYNAKÇA}

Aiken, L. S., West, S. G. \& Reno, R. R. (1991). Multiple regression: Testing and interpreting interactions. Sage Publications.

Amabile, T. M. (1983). The social psychology of creativity: A componential conceptualization. Journal of Personality and Social Psychology, 45(2), 357.

Amabile, T. M. (1997). Motivating creativity in organizations: On doing what you love and loving what you do. California Management Review, 40(1), 39-58.

Anderson, J. C. \& Gerbing, D. W. (1988). Structural equation modeling in practice: $\mathrm{A}$ review and recommended two-step approach. Psychological Bulletin, 103(3), 411.

Andersson, L. M. \& Pearson, C. M. (1999). Tit for tat? The spiraling effect of incivility in the workplace. Academy of Management Review, 24(3), 452-471.

Bagozzi, R. P. \& Yi, Y. (1988). On the evaluation of structural equation models. Journal of the Academy of Marketing Science, 16(1), 74-94.

Baron, R. M. \& Kenny, D. A. (1986). The moderatormediator variable distinction in social psychological research: Conceptual, strategic, and statistical considerations. Journal of Personality and Social Psychology, 51(6), 1173.

Bauer, T. N. \& Erdoğan, B. (2016). The oxford handbook of leader-member exchange (T. N. Bauer \& B. Erdoğan Eds.). New York: Oxford University Press.

Bauer, T. N. \& Green, S. G. (1996). Development of leader-member exchange: A longitudinal test. Academy of Management Journal, 39(6), 1538-1567.

Blau, P. (2017). Exchange and power in social life. London: Routledge.

Brislin, R. W. (1980). Translation and content analysis of oral and written materials. In J. W. Berry \& H. C. Triandis (Eds.), Handbook of Cross-Cultural Psychology (Vol. 2, pp. 389-444).

Burchell, M. \& Robin, J. (2011). The great workplace how to build it, how to keep it and why it matters. San Francisco: Jossey-Bass.

Burmaoğlu, S. Polat, M., \& Meydan, C. H. (2013). Örgütsel davranış alanında ilişkisel analiz yöntemleri ve Türkçe yazında aracılık modeli kullanımı üzerine bir inceleme. Anadolu Üniversitesi Sosyal Bilimler Dergisi, 13(1), 13-26.

Coelho, F. Augustob, M., \& Lages, L. F. (2011). Contextual factors and the creativity of frontline employees: The mediating effects of role stress and 
intrinsic motivation. Journal of Retailing, 87(1), 3145 .

Cohen, L. Manion, L., \& Morrison, K. (2002). Research methods in education. London: Routledge.

Cohen, P. West, S. G., \& Aiken, L. S. (2014). Applied multiple regression/correlation analysis for the behavioral sciences. London: Psychology Press.

Cortina, L. M. \& Magley, V. J. (2001). Incivility in the workplace: Incidence and impact. Journal of Occupational Health Psychology, 6(1).

Cortina, L. M. \& Magley, V. J. (2009). Patterns and profiles of response to incivility in the workplace. Journal of Occupational Health Psychology, 14(3), 272.

Cortina, L., M. Magley, V. J., Williams, J. H. \& Langhout, R. D. (2001). Incivility in the workplace: incidence and impact. Journal of Occupational Health Psychology, 6(1), 64.

Craney, T. A. \& Surles, J. G. (2002). Model-dependent variance inflation factor cutoff values. Quality Engineering, 14(3), 391-403.

Cummings, A. \& Oldham, G. R. (1997). Enhancing creativity: Managing work contexts for the high potential employee. California Management Review, 40(1), 22-38

Çiçek, B. \& Almalı, A. (2017). E-Devlet uygulamalarının lider üye etkileşimi üzerindeki etkisi. Route Educational \& Social Science Journal 4(8), 455-467.

Çiçek, B. \& Deniz, M. (2017). Liderlere ve organizasyonlara değer temelli yaklaşım: Değer merkezli liderlik ve etik iklim ilişkisi üzerine bir araştırma. Işsletme Araştırmaları Dergisi 9(2), 150168.

Dansereau, F. J., Graen, G. \& Haga, W. J. (1975). A vertical dyad linkage approach to leadership within formal organizations a longitudinal investigation of the role making process. Organizational Behavior and Human Performance, 13, 46-78.

Davis, W. D. \& Gardner, W. L. (2004). Perceptions of politics and organizational cynicism: An attributional and leader-member exchange perspective. The Leadership Quarterly, 15(4), 439-465.

Dienesch, R. M. \& Liden, R. C. (1986). Leader-member exchange model of leadership: A critique and further development. Academy of Management Review, 11(3), 618-634.

Dul, J. \& Ceylan, C. (2011). Work environments for employee creativity. Ergonomics, 54(1), 12-20.

Efron, B. \& Tibshirani, R. (1986). Bootstrap methods for standard errors, confidence intervals, and other measures of statistical accuracy. Statistical Science, 54-75.

Eichhorn, B. R. (2014). Common method variance techniques. Cleveland State University, Department of Operations \& Supply Chain Management. Cleveland, $\mathrm{OH}$ : SAS Institute Inc.

Estes, B. \& Wang, J. (2008). Integrative literature review: Workplace incivility: Impacts on individual and organizational performance. Human Resource Development Review, 7(2), 218-240.

Falk, C. F. (2017). Mediation analysis. Retrieved from: http://www.psych.mcgill.ca/perpg/fac/falk/mediation. $\mathrm{html}$

Felblinger, D. M. (2008). Incivility and bullying in the workplace and nurses' shame responses. Journal of Obstetric, Gynecologic \& Neonatal Nursing, 37(2), 234-242.

Fornell, C. \& Larcker, D. F. (1981). Evaluating structural equation models with unobservable variables and measurement error. Journal of Marketing Research, $39-50$.

Gallos, J. V. (2008). Business leadership: A jossey-bass reader. San Francisco: Jossey- Bass.

George, J. M. \& Brief, A. P. (1992). Feeling good-doing good: A conceptual analysis of the mood at workorganizational spontaneity relationship. Psychological Bulletin, 112(2), 310-329.

George, J. M. \& Zhou, J. (2001). When openness to experience and conscientiousness are related to creative behavior: An interactional approach. Journal of Applied Psychology, 86(3), 513-524.

Gerstner, C. R. \& Day, D. V. (1997). Meta-Analytic review of leader-member exchange theory: Correlates and construct issues. Journal of Applied Psychology, 82(6), 827.

Gong, Y., Huang, J.-C. \& Farh, J.-L. (2009). Employee learning orientation, transformational leadership, and employee creativity: The mediating role of employee creative self-efficacy. Academy of Management Journal, 52(4), 765-778.

Gouldner, A. W. (1960). The norm of reciprocity: A preliminary statement. American Sociological Review, 161-178.

Graen, G. B. \& Liden, R. C. (1982). Role of leadership in the employee withdrawal process. Journal of Applied Psychology, 67(6), 868-872.

Graen, G. B. \& Uhl-Bien, M. (1995). Relationship-based approach to leadership: Development of leadermember exchange (LMX) theory of leadership over 25 years: Applying a multi-level multi-domain perspective.The Leadership Quarterly, 6(2), 219-247. 
Gupta, V. \& Singh, S. (2014). Leadership and creative performance behaviors in R\&D laboratories: Examining the mediating role of justice perceptions. Journal of Leadership \& Organizational Studies, 22(1), 1-16.

Gutnick, D., Walter, F., Nijstad, B. A. \& Dreu, C. K. W. D. (2012). Creative performance under pressure. Organizational Psychology Review, 2(3), 189-207.

Hair, J. F., Black, W. C., Babin, B. J., Anderson, R. E. \& Tatham, R. L. (2006). Multivariate data analysis (6th Edition). Pearson Prentice Hall. New Jersey.

Harman, H. H. (1967). Modern factor analysis. Chicago: University of Chicago Press.

Hayes, A. F. (2017). Introduction to mediation, moderation, and conditional process analysis: A regression-based approach. Guilford Publications.

Henseler, J., Ringle, C. M. \& Sarstedt, M. (2015). A new criterion for assessing discriminant validity in variance-based structural equation modeling. Journal of The Academy of Marketing Science. 43(1), 115135.

Hu, L. T. \& Bentler, P. M. (1999). Cutoff criteria for fit indexes in covariance structure analysis: Conventional criteria versus new alternatives. Structural Equation Modeling: a Multidisciplinary Journal, 6(1), 1-55.

Hur, W. M., Moon, T. \& Jun, J. K. (2016). The effect of workplace incivility on service employee creativity: The mediating role of emotional exhaustion and intrinsic motivation. Journal of Services Marketing, 30(3), 302-315.

Hutton, S. A. (2006). Workplace incivility: State of the science. JONA: The Journal of Nursing Administration, 36(1), 22-27.

Iacobucci, D., Saldanha, N. \& Deng, X. (2007). A meditation on mediation: Evidence that structural equations models perform better than regressions. Journal of Consumer Psychology, 17(2), 139-153.

Kline, R. B. (2005). Principles and practice of structural equation modeling. New York: Guilford Press.

LaGrange, R. L., Ferraro, K. F. \& Supancic, M. (1992). Perceived risk and fear of crime: Role of social and physical incivilities. Journal of Research in Crime and Delinquency, 29(3), 311-334.

Leiter, M. (2013). Analyzing and theorizing the dynamics of the workplace incivility crisis. Canada: Springer.

Lutgen-Sandvik, P., Tracy, S. J. \& Alberts, J. K. (2007). Burned by bullying in the american workplace: Prevalence, perception, degree and impact. Journal of Management Studies, 44(6), 837-862.
Madjar, N., Oldham, G. R. \& Prat, M. G. (2002). There's no place like home? The contributions of work and nonwork creativity support to employees' creative performance. Academy of Management Journal, 45(4), 757-767.

Mallinckrodt, B., Abraham, W. T., Wei, M. \& Russell, D. W. (2006). Advances in testing the statistical significance of mediation effects. Journal of Counseling Psychology, 53(3), 372.

Maslyn, J. M. \& Uhl-Bien, M. (2001). Leader-member exchange and its dimensions: Effects of self-effort and other's effort on relationship quality. Journal of Applied Psychology, 86(4), 697.

Northouse, P. G. (2010). Leadership theory and practice. Los Angeles: Sage Publications.

Oldham, G. R. \& Cummings, A. (1996). Employee creativity: Personal and contextual factors at work. Academy of Management Journal, 39(3), 607-634.

Oxford. (2019). Incivility. Retrieved from: https://www.oxfordlearnersdictionaries.com/definitio n/english/incivility?q=incivility

Pan, W., Sun, L. Y. \& Chow, I. H. S. (2012). Leadermember exchange and employee creativity: Test of a multilevel moderated mediation model. Human Performance, 25(5), 432-451.

Pearson, C. M., Andersson, L. M. \& Porath, C. L. (2000). Assessing and attacking workplace incivility. Organizational Dynamics, 29(2), 123-137.

Penney, L. M. \& Spector, P. E. (2005). Job stress, incivility, and counterproductive work behavior (CWB): The moderating role of negative affectivity. Journal of Organizational Behavior, 26(7), 777-796.

Pfifferling, J.-H. (2003). Developing and implementing a policy to deal with disruptive staff members. Oncology Issues, 18(3), 16-21.

Porath, C. L., Foulk, T. \& Erez, A. (2015). How incivility hijacks performance. Organizational Dynamics, 44(4), 258-265.

Sadler, P. (2003). Leadership. London: Kogan Page.

Sakurai, K. \& Jex, S. M. (2012). Coworker incivility and incivility targets' work effort and counterproductive work behaviors: The moderating role of supervisor social support. Journal of Occupational Health Psychology, 17(2), 150.

Sguera, F., Bagozzi, R. P., Huy, Q. N., Boss, W. R. \& Boss, D. S. (2016). Curtailing the harmful effects of workplace incivility: The role of structural demands and organization-provided resources. Journal of Vocational Behavior, 95(96), 115-127.

Shalley, C. E. \& Gilson, L. L. (2004). What leaders need 
to know: A review of social and contextual factors that can foster or hinder creativity. The Leadership Quarterly, 15(1), 33-53.

Sivo, S. A., Fan, X., Witta, E. L. \& Willse, J. T. (2006). The search for" optimal" cutoff properties: Fit index criteria in structural equation modeling. The Journal of Experimental Education, 74(3), 267-288.

Sliter, M. T., Pui, S. Y., Sliter, K. A. \& Jex, S. M. (2011). The differential effects of interpersonal conflict from customers and coworkers: Trait anger as a moderator. Journal of Occupational Health Psychology, 16(4), 424.

Solomon, R. C. (1998). The moral psychology of business: Care and compassion in the corporation. Business Ethics Quarterly, 8(3), 515-533.

Tabachnick, B. G., Fidell, L. S. \& Ullman, J. B. (2007). Using multivariate statistics (Vol. 5). Boston, MA: Pearson.

Tavşancıl, E. (2002). Tutumların ölçülmesi ve SPSS ile veri analizi. Ankara: Nobel Yayıncılık.

Türk Dil Kurumu. (2019). Nezaketsizlik. Retrieved from: https://sozluk.gov.tr/.

Thompson, G., Buch, R. \& Glasø, L. (2018). Low-quality LMX relationships, leader incivility, and follower responses. Journal of General Management, 44(1), $17-26$.

Tierney, P. \& Farmer, S. M. (2004). The pygmalion process and employee creativity. Journal of Management, 30(3), 413-432.

Tierney, P., Farmer, S. M. \& Graen, G. B. (1999). An examination of leadership and employee creativity: The relevance of traits and relationships. Personnel Psychology, 52(3), 591-620.

Türkiye İstatistik Kurumu. (2019). Retrieved from: http://www.tuik.gov.tr/PreTablo.do?alt_id=1059

Unsworth, K. (2001). Unpacking creativity. Academy of Management Review, 26(2), 289-297.

Urbach, N. \& Ahlemann, F. (2010). Structural equation modeling in information systems research using partial least squares. Journal of Information Technology Theory and Application, 11(2), 5-40.

Vidyarthi, P. R., Liden, R. C., Anand, S., Erdogan, B. \& Ghosh, S. (2010). Where do i stand? Examining the effects of leader-member exchange social comparison on employee work behaviors. Journal of Applied Psychology, 95(5), 849-861.

Walumbwa, F. O., Cropanzano, R. \& Hartnell, C. A. (2009). Organizational justice, voluntary learning behavior and job performance: A test of the mediating effects of identification and leader-member exchange.
Journal of Organizational Behavior, 30(8), 11031126.

Waples, E. P. \& Friedrich, T. L. (2011). Managing creative performance: Important strategies for leaders of creative efforts. Advances in Developing Human Resources, 13(3), 366-385.

Wayne, S. J., Shore, L. M. \& Liden, R. C. (1997). Perceived organizational support and leader-member exchange: A social exchange perspective. Academy of Management Journal, 40(1), 82-111.

Zhan, X., Li, Z. \& Luo, W. (2019). An identification - based model of workplace incivility and employee creativity: evidence from China. Asia Pacific Journal of Human Resources, 57(4), 528-552.

Zhou, J. \& Shalley, C. E. (2003). Research on employee creativity: A critical review and directions for future research. In Research in personnel and human resources management (pp. 165-217). Emerald Group Publishing Limited.

Zinbarg, R. E., Revelle, W., Yovel, I. \& Li, W. (2005). Cronbach's $\alpha$, Revelle's $\beta$, and McDonald's $\omega \mathrm{H}$ : Their relations with each other and two alternative conceptualizations of reliability. Psychometrika, 70(1), 123-133. 